\title{
降圧チョッパによる蛍光ランプ用定電力形安定器
}

\author{
i: 会員 水野 銛章* 川: 会員 矢橋 清二* 専門会員 石川 太郎*
}

\section{A Fluorescent Lamp Ballast Based On Current-boost Chopper Circuit}

\author{
Toshiaki Mizuno (Member) Seiji Yabashi (Member) \\ and Taro Ishikawa (Fellow Member) \\ (Department of Electronics, Nagoya Institute of Technology)
}

\begin{abstract}
The ballast is composed of a rectifying unit, a filter capacitor, a chopper circuit and a control circuit. The chopper circuit has an inductor of a several $\mathrm{mH}$, a high-power switching transistor and a semiconductor diode. The control circuit is a pulse-width-modulator with an error amplifier, and regulates the lamp current to maintain at a preset value.

The ballast has a high efficacy only for vertically operating lamps. When a horizontally operating lamp is burned with the ballast, because of d. c. component of the lamp current, the light output decreases in the neighborhood of the anode and the total flux or the efficacy becomes small. But when the lamp is placed the cathode up and the anode down, the luminescence is almost homogeneous over the tube surface and high efficacy is obtained.

The ballast of light weight is achieved, because no transformer is used and the control circuit is replaced by an IC. Moreover, the ballast is compatible for both 50 and $60 \mathrm{~Hz}$ of line frequency, and the change of the power or the light output is small with a fluctuation of the line voltage. But the lamp operating position must be limited in the vertical plane.
\end{abstract}

\section{1. ま え がき}

蛍光ランプの安定器には, 従来チョークコイルや磁気漏れ変压: 器が使われてきたが, 最近, 小型軽量化と高効率化のために電子. 回路化が研究され実用化も始まっている1). 現在市販されている 全電子化安定器は, 高周波トランスと 2 個のパワートランジスタ を使用するものが大半である.

降压チョッパ（電流ブースト・チョッパ）回路を用いた安定 器2) 4) は, 回路が簡単であるといら特長を持つが, その出力電流 は淔流分を含んでいる，蛍光ランプを直流で長時間点灯するとカ タホレシス(cataphoresis)現象により，陽極側に隌端を生ずる56) ことが知られているので, 降压チョッパによる安定器は営光ラン プの点灯には不適当のように思われた. しかし蛍光ランプの点灯 方向を鈆直面内で変えて㬰験を行なった結果, 暗端を生じない点 灯方向があることがわかった.このよらな場合について降压チ ッパ式安定器による点灯特性について報告する.

* 名古屋工業大学奄子工学科

本論文の一部は, 昭和57年度照明学会全国大会 36 , 叔よび昭和58年度照明学:会全国 大会28にて発表したものである.

\section{2. 蛍光ランプの直流点灯特性}

カタホレシスは, 混合気体中の直流放電に拈いて成分気体が分 離する現象で, 希ガスと水銀との混合気体については1934年Penning により観測され?，1935 年 Druyvesteyn により解析がなさ $れ^{8)}$, その後, この Druyvesteyn の理論の修正が行なわれてい $ろ^{9)}$. 蛍光ランプでは, 水銀イオンが電界により㓌極方向に移動 し陰極で中性原子に㞍るため, 陰極付近の水銀原子密度を増加さ せ陽極付近では減少させる．この原子密度のこう配のために陽極 方向への逆払散を生ずるが，管長が長いため拡散が十分行なわれ ないので，陽極付近では水銀原子密度が小さくなり発光も弱くな る. ランプを垂值点灯したときには，水銀原子の質量は電子の $3.6 \times 10^{5}$ 倍であるので, 電子に働く重力は無視できても, 水銀原 子に働く重力は無視できないことが予想される．陰極を上にした ときには，重力は陰極に蓄積した水銀原子を陽極方向へ移動さ せ，カタホレシスを打ち消すであろう.

直管 $20 \mathrm{~W}$ 䖢光ランプを垂直位置において点灯したときの，管

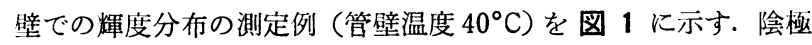
を上にした場合は，(a)に示すように陽光柱部分は一様に発光して いる，陰極を下にした場合には，(b)に示すように陽極付近が㳂い 


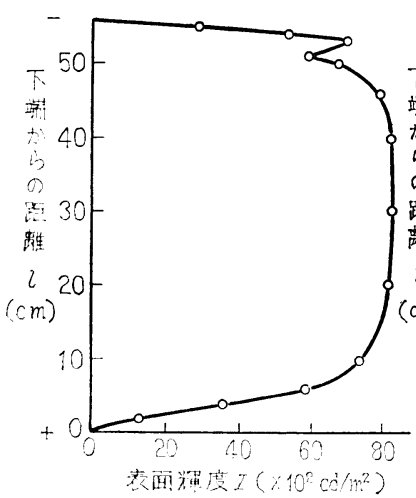

(a)

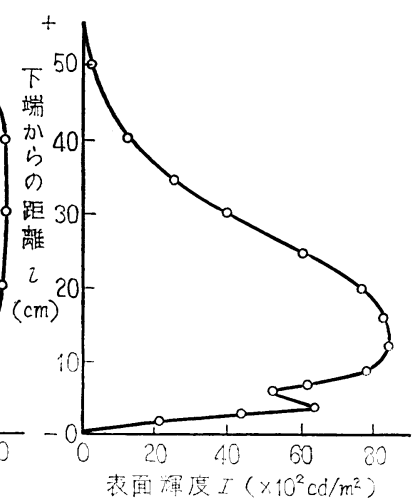

(b)
图 1 垂㨁点灯に㧍ける管壁の辉度分布

(a) 陰極を上にしたとき（b) 陰極を下にしたとき

籁囲にわたって隌くなっている。

\section{3. 降圧チョッパ回路による安定器}

商用交流を電源とする安定器をを図 2 に, 制御回路を図 3 に 示す. 図 1 において $L_{1}$ は数 $\mathrm{mH}$ のコイル $\operatorname{Tr}$ はスイッチング動 作をするパワートランジスタ， $\mathrm{D}_{1}$ は半導体ダイオードであり， これらが降圧チョッパ回路を構成する． $R_{1}$ は電流検出用抵抗で あり，そこでの電左降下は $R_{2}, C_{1}$ を経て制御回路に加えられ制 御回路は $R_{\mathbf{1}}$ の電压降下の平均值を基準電生と比較して, 降压: ョッパ回路の入力電流を一定に保つように, Tr の on 時間と off 時間との比を制御する．また図 1 の $R_{3}$ と $R_{4}$ は電源電圧に比例 した電圧を制御回路に加えるので， $R_{3}$ と $R_{4}$ との比を適当に選ぶ と, 電源電压の変動による入力電力の変化を小さくすることがで きるなお $L_{f}$ と $C_{f}$ は雑暗防此用フィルタである。

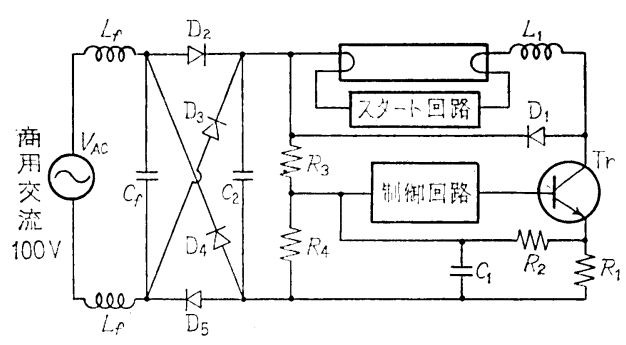

图 2 降左チョッパ回路に上る䖝光ランプ用安定器

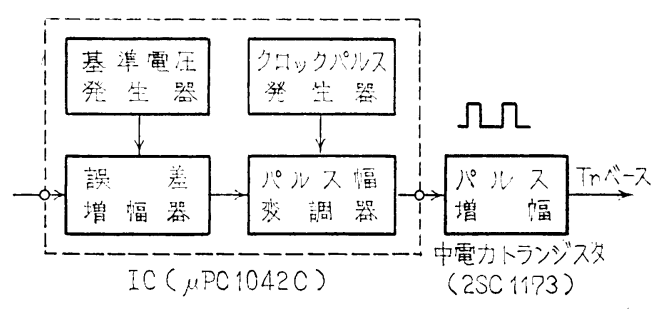

图 3 制御回路

\section{4. 実 験 結 果}

降压チョッパ式安定器を用いて, 水平面内に置かれた蛍光ラン プを点灯すると，直流点灯の場合と同じように数時間たつと陽極 側に発光の弱い部分を生じ全光束も減少する. ランプを鈖直面内 に置き点灯方向を変えて実験を行なった結果, 図 4 に示すよう に直管形および環形ランプでは，除極が上に陽極が下になるよう な位置で，U形ランプでは口金が上にくるような位置で使用すれ ば管全体が大体一㥞に発光し, 光束の滅少も少ないことがわかっ (a)

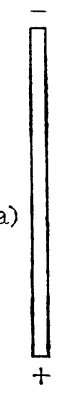

(b)

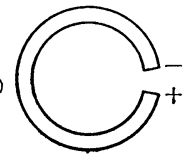

(c)

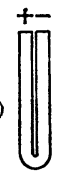

た.

\section{1 直管形 $20 \mathrm{~W}$ Wンプの点灯}

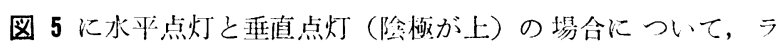
ンプ主面の輝度分布を示す。ここで，横軸は㓌極側の端からの距 離を装わす。水平点灯では陽極に近い汪らの約半分に薯しく発光

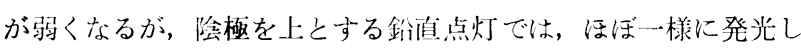
ていることがわかる.
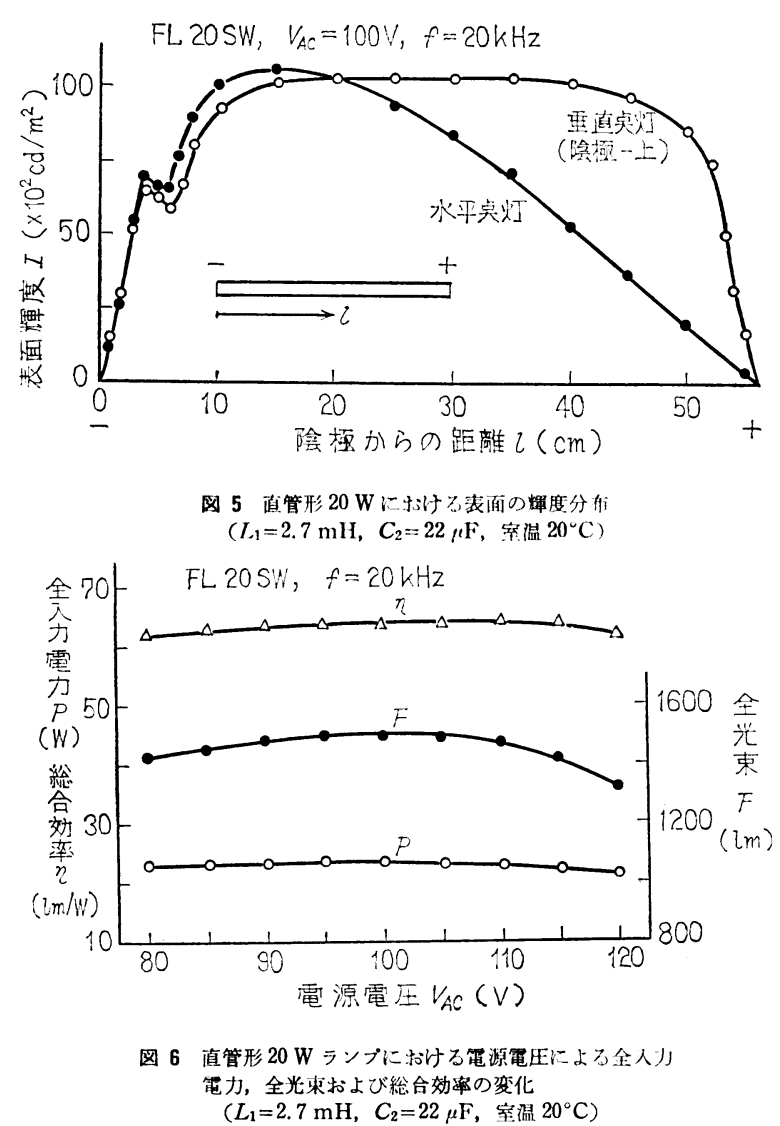

鉛直点灯の場合の電源電压による全入力電力, 企光束掞よび総 合効摔 (全光束/全入力電力) の変化を 図 6 に示与が, 電源電 止 $100 \mathrm{~V} \pm 10 \%$ の変化に対して, 電力と光束の変化は土 $3 \%$ 以内 である.またトリガ周波数による入力電力, 光束および総合効花 の変化を图 7 に示すが, トリガ周波数には汪とんど無関係であ ることがわかる.

このランプを市販のチョークコイル式安定器で点灯すると, 令 入力電力 $23 \mathrm{~W}$, 全光束 $1,270 \mathrm{~lm}$, 総合効率 $55 \mathrm{~lm} / \mathrm{W}$ であるが, 降坧チョッパ式安定器を使用し, 全入力電力を同じ $23 \mathrm{~W}$ とする と, 全光束 $1,470 \mathrm{~lm}$, 総合効率 $64 \mathrm{~lm} / \mathrm{W}$ となり, 効率は約 $16 \%$ 


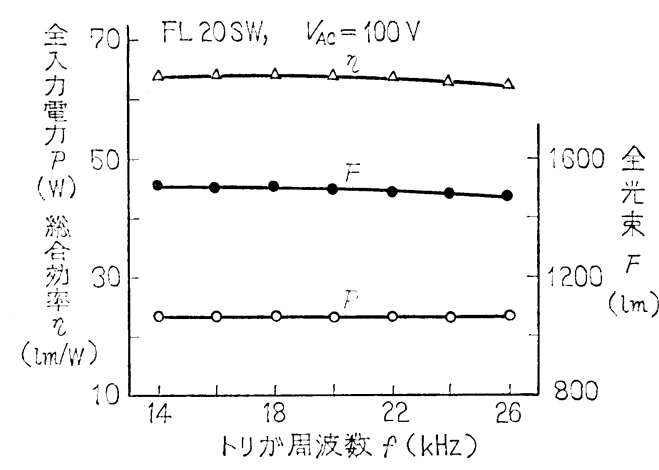

国 7 直管形 $20 \mathrm{~W}$ ランプに括けるトリガ周波数に上 万全入力电力, 全光束执上び総合効洋の驾化 $\left(L_{1}=2.7 \mathrm{mH}, C_{2}=22 \mu \mathrm{F}\right.$, 室温 $\left.20^{\circ} \mathrm{C}\right)$

向上与る。

\section{2 環形 $30 \mathrm{~W}$ ランプの点灯}

ランプ表面の輝度分布を，ランプの位置が水平面内にあるとき と，鉛直面内（図 $4(\mathrm{~b})$ ) にあるときについて 図8 に示す. 水平 面内にあるときには，陽極側に近い汪うの約半分が暗くなってい るが，鉛直面内にあるときには大体一様澄光していることがわ， かる.

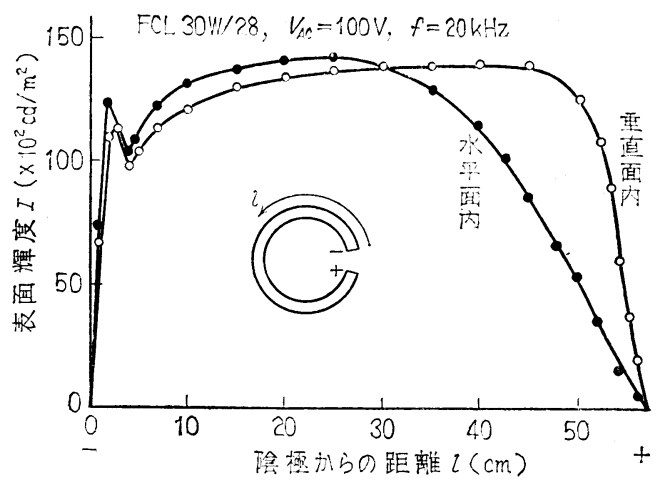

图 8 理形 $30 \mathrm{~W}$ ランプに拟方表面の蝀度分有 $\left(L_{1}=2.7 \mathrm{mH}, C_{2}=22 \mu \mathrm{F}\right.$, 室温 $\left.20^{\circ} \mathrm{C}\right)$

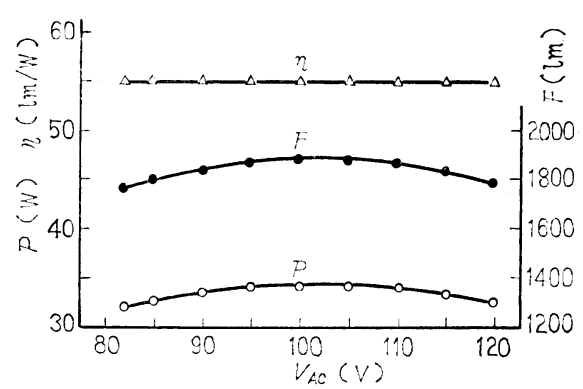

Lamp $=$ FCL $30 \mathrm{~W} / 28, f=20 \mathrm{kHz}, L=2.7 \mathrm{mH}$

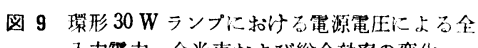
入力筆力, 全光束および総合効率の変化 $\left(L_{1}=2.7 \mathrm{mH}, C_{2}=22 \mu \mathrm{F}\right.$, 空温 $\left.20^{\circ} \mathrm{C}\right)$

鉛值面内点灯のときの電源電比にる全入力電力, 全光资, 小 よで総合効率の変化を図 9 に示与. 電源電压が $85 \mathrm{~V}$ から 120 $\mathrm{V}$ の範囲では電力と光束の変化は約 $6 \%$ である.

トリガ周波数による全入力電力, 全光束拈上び総合効辩の変化 を図 10 に示す.

このランプを市敗のチョークコイル式安定器で点灯すると，全 入力電力 $34 \mathrm{~W}$, 全光束 $1,670 \mathrm{~lm}$, 総合效摔 $49 \mathrm{~lm} / \mathrm{W}$ であるが, 降圧チョッパ式安定器では, 全入力電力を同じ $34 \mathrm{~W}$ とする之, 全光束 $1,880 \mathrm{~lm}$, 総合効率 $55 \mathrm{~lm} / \mathrm{W}$ となり, 効率は約 $12 \%$ 高く

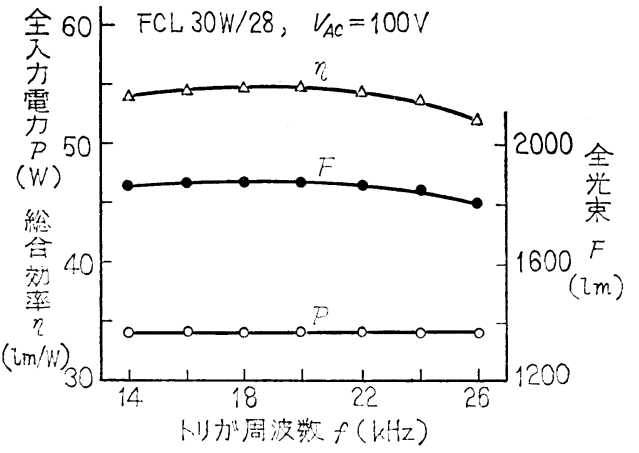

图 10 壊形 $30 \mathrm{~W}$ フンプにおけるトリガ周波数に上る

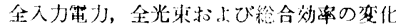
$\left(L_{1}=2.7 \mathrm{mH}, C_{2}=22 \mu \mathrm{F}\right.$, 室温 $\left.20^{\circ} \mathrm{C}\right)$

なる。

\section{4. $3 \mathrm{U}$ 形 $18 \mathrm{~W}$ ランプの点灯}

図 4 (c)に示すように口金が上になるよう位置で点灯すると，

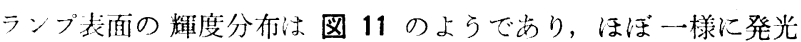
している. 図 12 は電源電压による全入力電力, 全光束および総

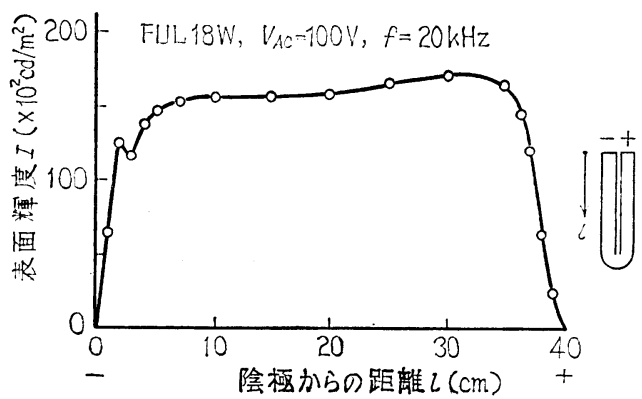

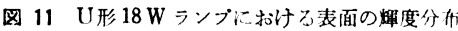
$\left(L_{1}=2.7 \mathrm{mH}, C_{2}=22 \mu \mathrm{F}\right.$, 室湍 $20^{\circ} \mathrm{C}$ )

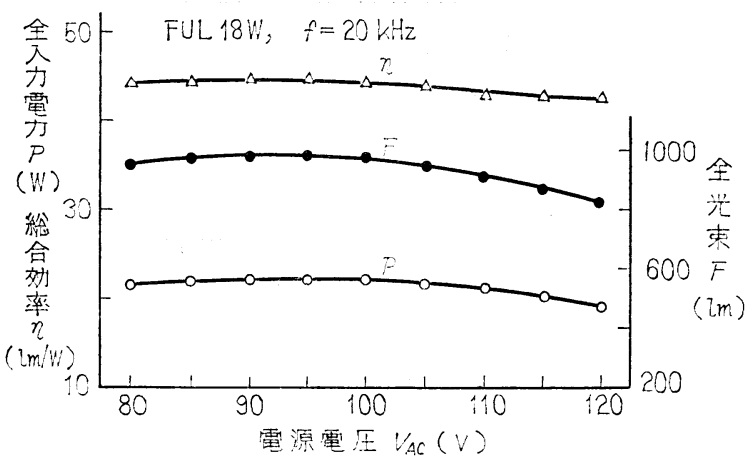

图 12 U形 $18 \mathrm{~W}$ ランプ:扎ける龟源電圧の变化に上 る全入力䉓力，全光束扰よび旒合効率の変化 $\left(L_{1}=2.7 \mathrm{mH}, C_{2}=22 \mu \mathrm{F}\right.$, 室温 $\left.20^{\circ} \mathrm{C}\right)$

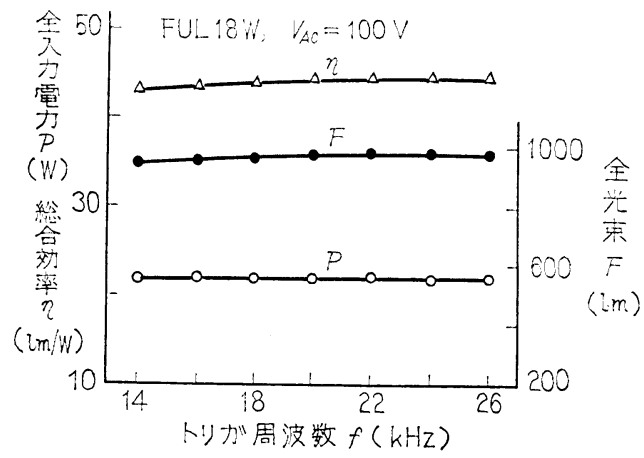

图 13 U形 18 W ランプに批るトリガ周波数による 全入力䒜力, 全光束および総合效率の变化 $\left(L_{1}=2.7 \mathrm{mH}, C_{2}=22 \mu \mathrm{F}\right.$, 室温 $\left.20^{\circ} \mathrm{C}\right)$ 
合効率の变化を示すが，電源電圧 $100 \mathrm{~V} \pm 10 \%$ の变動に対して, 電力と光束の変化は約 $\pm 3 \%$ である. 図 13 はトリガ周波数によ る全入力電力, 全光束および総合効率の変化を示すが, トリガ周 波数にはほとんど無関係である.

このランプをチョークコイル式安定器で点灯したときは, 全入 力電力 $22 \mathrm{~W}$, 全光束 $900 \mathrm{~lm}$, 総合效率 $41 \mathrm{~lm} / \mathrm{W}$ であるが, 降川: チョッパ式灾定器で, 全入力雨力を同じ $22 \mathrm{~W}$ としたときには,

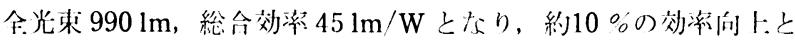
なった。

\section{4 整流平滑回路とフリッカについて}

この安定器では, 商用交流を整流平滑した直流を降压チョッパ の入力としているので光束のフリッカが小さい，平滑コンデンサ の容量を大きくするとフリッカは少なくなるが, 安定器の容積は 大きくなり総合効率も徐々に低下する，この容量が小さすぎると 整流出力電压の脈動が大きくなり，放電の休止期間を生ずるので 総合効率が急速に低下する．上述の実験では平滑コンデンサの容 量は $30 \mu \mathrm{F}$ である. $30 \mathrm{~W}$ のランプを点灯しているときの整流出 力電生 $\left(V_{D C}\right)$ と光束の波形を 図 14 (a), (b) に示亦. また比

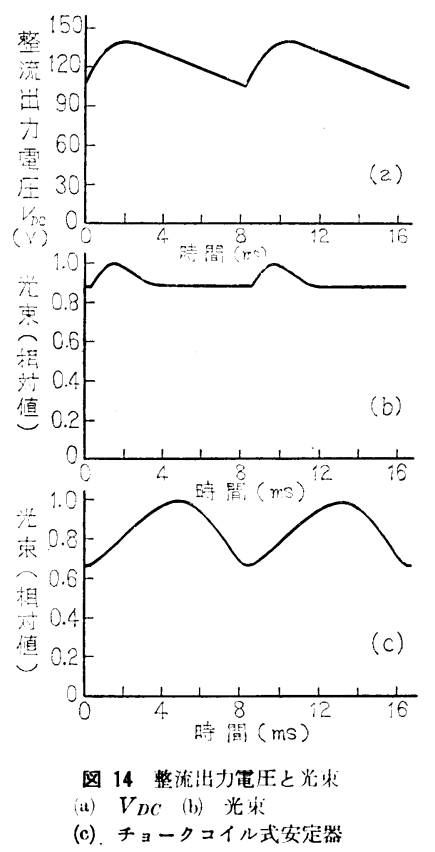

較のため, 市販のチョークコイル式安定器を使ったときの光束の 波形を同図（c）に示す，パーセント・フリッカは, チョークコ イル式で約 $20 \%$ であるのに対し，この安定器では約 $7 \%$ であっ た.

\section{5. ま と め}

蛍光ランブを水平位置で直流点灯すると，陽極側に瞕部を生じ 企光束む低下するが，陰極を上にした重直位置で使用すれば一様 に発光する.このような場合に限定すれば降压チョッパ式安定器 は次の特長を持っている。

（1）変压器を使用しないので，重量をチョークコイル式の約半 分にできる.

（2）商用電源を整流・平滑しているので， $50 \mathrm{~Hz}, 60 \mathrm{~Hz}$ 共用の 安定器となりフリッカを小さくできる.

（3）電源電纴の变動による電力や，光束の变化を小さくできる ので $100 \mathrm{~V}, 115 \mathrm{~V}$ 共用の安定器とすることもできる.

(4) 二, 三の回路定数を変更するだけで，種々の定格のランプ のための安定器を製作できる.

この安定器は, ランブの点灯方向が限定されるという短所があ る. しかし，直管形および環形ランプの器具を壁面や柱に取り付 けて使用ナる場合や，U形ランプを適当な反射がさとともに天井 に取り付けたり，つり下げたりする場合には，この安定器は有用 であろう。

この方式の安定器の実用化には, さらにいろいろな試験や検討 が必要であろらが，小型軽量で高効率な照明器具の開発汇役立てて ばと思い報告する。

参考文献

（1）野村汪か：照学茫 64 (㯕55) 103

(2) Schiff, P.: Electronics Aug. 5 (1968) 130

（3）特公炤 47-193 实案昭 50-111182

（4）水野注か：照学誌 66 (昭57) 121

(5) 照明学会編：照明ハンドブック（昭53）第 6 章

(6) Elenbaas, W.: Light Sources, Macmillan Press. (1972) Chap 5

(7) Penning. F. M.: Physica 1 (1934) 763

(8) Druyvesteyn, M. J.: Physica 2 (1935) 255

(9) Loeb, L. B.: J. Appl. Phys 29 (1958) 1369

（受付 1983 年 5 月 2 日) 